\title{
Thinking citizenship and its constitutive subject: Interrogating the 2004 Irish citizenship referendum debate
}

DOI:

10.1080/13621025.2011.549704

\section{Document Version}

Final published version

Link to publication record in Manchester Research Explorer

\section{Citation for published version (APA):}

Ní Mhurchú, A. (2011). Thinking citizenship and its constitutive subject: Interrogating the 2004 Irish citizenship referendum debate. Citizenship Studies, 15(2), 161-180. https://doi.org/10.1080/13621025.2011.549704

\section{Published in:}

Citizenship Studies

\section{Citing this paper}

Please note that where the full-text provided on Manchester Research Explorer is the Author Accepted Manuscript or Proof version this may differ from the final Published version. If citing, it is advised that you check and use the publisher's definitive version.

\section{General rights}

Copyright and moral rights for the publications made accessible in the Research Explorer are retained by the authors and/or other copyright owners and it is a condition of accessing publications that users recognise and abide by the legal requirements associated with these rights.

\section{Takedown policy}

If you believe that this document breaches copyright please refer to the University of Manchester's Takedown Procedures [http://man.ac.uk/04Y6Bo] or contact uml.scholarlycommunications@manchester.ac.uk providing relevant details, so we can investigate your claim.

\section{OPEN ACCESS}




\title{
Thinking Citizenship and its Constitutive Subject: Interrogating the 2004 Irish Citizenship Referendum Debate
}

\author{
Aoileann Ní Mhurchú
}

School of Law and Government, Dublin City University, Republic of Ireland

School of Law and Government, Dublin City University, Glasnevin, Dublin 9, Rep. of Ireland, (00353) 868647298, aoileann.nimhurchu@dcu.ie

Published in Citizenship Studies 15, No.2 (2011), pp.161-180

\section{ABSTRACT}

This article considers a referendum which was held in the Republic of Ireland in 2004 involving a proposal to qualify the existing universal constitutional entitlement to birthright citizenship. Existing analysis of this referendum reflects dominant trends in citizenship scholarship. It does so by framing the issue in terms of two opposing perspectives - one particularistic (exclusive), one universalistic (inclusive) - and positing the question of the 'politics' of citizenship as a trade-off between these diverging models. This article argues, however, that Rob (R.B.J.) Walker's notion of the constituent subject of (sovereign) politics challenges this dualistic framework as the necessary starting point for discussions about citizenship. It does so by problematizing the premise upon which it is based which is the taken-for-granted autonomous existence of persons (individuals) who are understood to be connected to, but ultimately separate from, 'the state'. The article concludes with reflections on what an alternative framework for exploring citizenship (based specifically on a historicization of subjectivity in relation to sovereignty) might look like. It suggests that this provides us with a different starting point to the prevalent form of a timeless dialectic of inclusion and exclusion, particularism and universalism, polis and cosmopolis currently determined by the boundaries of the Irish state.

Keywords: 2004 Irish citizenship referendum; Republic of Ireland; Rob Walker; subjectivity; sovereignty; autonomy; individual; difference

\section{Introduction}

Citizenship [...] names a site at which our constitutive account of what we are supposed to be will become less plausible, and where the highly problematic character of what we think politics is and where it occurs will become increasingly pronounced. [...] [B]ut there is no point in pushing at these limits [...] without also pushing at the account of modern subjectivity which has been produced by, and is productive of, those limits. (Walker 1999, p.198)

In 2004 the issue of citizenship became a heated topic of debate across the Republic of Ireland. This followed a proposal to modify, via referendum, the existing automatic constitutional entitlement to birthright citizenship. The existing automatic constitutional entitlement to birthright citizenship, inserted in 1998 as Article 2, 
declared that it was both the entitlement and birthright of "every person born in the island of Ireland...to be part of the Irish Nation and to be citizens of Ireland. ${ }^{1}$ In 2004 it was proposed to amend this by inserting a new clause into the Consitution which would qualify (via a residency requirement) Irish citizenship at birth for children born to non-national parents. A 'non-national' is defined under the Irish Nationality and Citizenship Act 2001 as 'a person who is not an Irish citizen'. ${ }^{2}$ This referendum was eventually passed by a $79.2 \%$ majority. ${ }^{3}$

Existing analysis of the 2004 Citizenship Referendum frames the issue as a clash between opposing perspectives. One perspective appeals to an exclusive concept of citizenship by relying on the notion of the primacy of the modern polis (nation) as the rightful (and only realistic) basis for an Irish political community. This perspective is associated with a civic republican conception of citizenship which promotes an understanding of citizenship as tied to rights but also to duties and responsibilities (understood as 'connections') which individuals have to a particular state. It therefore emphasizes the need to qualify entitlement to citizenship accordingly. ${ }^{4}$ The alternative perspective critiques the former as being based on narrow racialized understandings of Irishness and defends a more inclusive notion of citizenship by appealing to post-racial cosmopolitan imagery which is not dictated by a statist monopoly on understandings of modern political community and identity. This framing of the question of the 'politics' of citizenship as a negotiation of preferences between bounded citizenship (particularism) and post-national citizenship (universalism) reflects dominant trends in international citizenship scholarship. Over the past three decades these have begun to focus increasingly on how the state constructs groups differently in society according to degrees of inclusion and exclusion (Yuval-Davis and Anthias 1989, Lister 1997, Goldberg 2002). This has 
meant moving away, most notably, from focusing on the way the state acts upon individuals to that of how 'the state itself forms the political project' (Yuval-Davis and Anthias 1989, p.6). This scholarship is, however, still based on an understanding that subjectivity must continue to be discussed in relation to the state, as that which defines the parameters of 'political' community as against social community, economic community, etc.

In contrast to this, and as the opening quote suggests, R.B.J Walker's work emphasizes the link between politics and its constitutive subject. In so doing, he historicizes the notion of sovereign and autonomous subjectivity, and questions the supposed obviousness itself of taking the state as analytical category in its own right, juxtaposed with an autonomous sovereign form of 'being' which is then either included or excluded. The point is that Walker enters this debate (what he calls 'the citizenship debate' (Walker 1999, p.172)) by contesting the assumption that subjectivity has to be defined vis-à-vis its relationship with the state. He points instead to the assumptions regarding autonomy and sovereignty which this assumes and (re)produces. His work therefore presents itself as a challenge to the belief that the existing framing of the debate on citizenship in 2004 completely exhausts our 'understandings of historical tendencies and [...] judgments of normative possibilities' (ibid, p.171) as these relate to the question of the politics of citizenship. Instead it suggests that the particular versus universal, inclusion versus exclusion lens through which citizenship is normally articulated, reflects important assumptions about what a politics of citizenship must look like due to its attachment to a specifically modern account of autonomous subjectivity (ibid). With this in mind I take Rob Walker's work (1999) in this area as a starting point for exploring the limitations of existing analysis of the 2004 Citizenship Referendum. 
My argument is that existing analysis of the 2004 Citizenship Referendum as set out in terms of particular versus universal conceptions of society, is not exhaustive insofar as it is possible to contest 'the premises that set this old duet in motion' (ibid, p.172). The article is divided into three sections. The first section considers the main arguments which have been put forward in favour and against the 2004 Citizenship Referendum. It also explores the dominant intellectual and theoretical explanations for these arguments. It discusses finally why and how these are normally articulated as two opposing models of citizenship. The aim of this section is to highlight the reliance of these interpretations on the notion of the individual (albeit often via a very deconstructed understanding) as the lowest unit of analysis who is understood in terms of their ability to hold rights always against the state. The second section then develops an analysis designed to problematize this framework. This is done using Rob Walker's notion of the constitutive subject of citizenship. It is pointed out that this specifically problematizes the notion itself of individuality - not only in its own right as has been done already in critical citizenship scholarship via gendered and ethnic understandings of subjectivity - but specifically as that which is understood as connected to, but separate from, the (Irish) state.

The final section outlines what a reconceptualized concept of citizenship based on this problematized framework would look like It suggests that the notion of a constitutive subject of citizenship presents us with a different starting point from which to approach questions regarding the politics of citizenship in the Republic of Ireland, to that which is currently offered. This is a starting point which destabilizes the inevitability of the current framework which takes for granted that we must read citizenship via an understanding of subjectivity as autonomous and separate from the state and therefore in terms of inclusionary versus exclusionary models. Unlike the 
existing framework, I emphasize that the aim here is no longer to attempt to 'resolve' the question of citizenship in the Republic of Ireland post 2004 via understandings of a more inclusive Irish statist project. Instead the aim of this alternative framework, is that of providing the possibility of reconceiving of subjectivity in terms other than those (pre)determined by the sovereign autonomous boundaries of the Irish state. These are terms which expressly mess with the clean lines which have been imposed on understandings that the relationship between politics (of citizenship) and subjectivity must be conceptualized in terms of identity (inside) versus difference (outside).

\section{The 2004 Irish citizenship referendum debate}

This section outlines the two sides of the debate as structured at the time of the Citizenship Referendum according to existing analysis. The point in doing so here is not to engage in yet another discussion as to whether in 2004 the proposed amendment to the constitution was based on a legitimate civic (sovereign) understanding of citizenship or, alternatively an ethnic (racist) understanding of citizenship as is currently focused on. Rather, as will become increasingly clear, the aim here is to begin to explore the manner in which both of these positions, as articulated here, leave unquestioned a modern concept of subjectivity which sits at the heart of this debate itself.

\section{Sovereign statehood}

On 10 March 2004 the Irish Government announced its plans to hold a referendum on the question of whether the existing universal constitutional right to birthright citizenship on the island of Ireland should be amended. A bill, which proposed that 
the following new section be added to Article 9 of Bunreacht na hÉireann (Irish Constitution, 1937), was initiated in Dáil Éireann (lower house) several weeks later:

Article 9.2.1 Notwithstanding any other provision of this Constitution, a person born in the island of Ireland, which includes its islands and seas, who does not have, at the time of his or her birth, at least one parent who is an Irish citizen or entitled to be an Irish citizen is not entitled to Irish citizenship or nationality, unless otherwise provided for by law. $^{5}$

The argument in favour of this qualification was articulated in several key documents produced by the then Fianna Fáil/Progressive Democrats coalition Government (Department of Justice 2004a, 2004b and 2004c). ${ }^{6}$ These explained that the issue of universal entitlement of all those born on the island of Ireland to be Irish citizens (inserted as Article 2 into the Irish Constitution in 1998) was impeding the Government's ability to assert its sovereign duty and regulate entry into, and residence within, the state. In light of a sustained increase in the numbers of persons born outside of the island of Ireland taking up residence over the previous decade ${ }^{7}$, the argument made was that universal automatic constitutional entitlement to citizenship at birth in Ireland was permitting children of persons (referred to as nonnationals) who did not have sufficient connection with Ireland to acquire significant rights which they might otherwise not be entitled to simply by virtue of being born in Ireland. This, according to the Government, was an abuse of the system and needed to be rectified via referendum so as to remove the universality of this entitlement from the Constitution. As proof of the abuse to which it referred, the Government pointed to a general increase since 1998 of births to non-nationals in the state (Department of Justice 2004c, p.8) and more recently to the specific experience at certain Dublin maternity hospitals of 'a disproportionate number' of non-national women presenting unannounced in both late pregnancy, and in the early stages of labour only to leave 
the country soon after giving birth (Oireachtas Debates 21 April 2004, p.1189). This practice was described as 'citizenship tourism' and it was argued that '[t]his [latter] phenomenon is directly related to the fact that Irish law at present gives to the children the entitlement to Irish citizenship and thus to citizenship of the European Union' (Department of Justice 2004b, p.5). The proposed citizenship referendum was accordingly presented as a 'simple' and 'sensible' effort by a sovereign state to deal with this issue (Progressive Democrats 2004) - the Fianna Fáil referendum campaign posters at the time reading 'Vote Yes to Commonsense Citizenship'.

In existing analysis of the 2004 Citizenship Referendum the pro referendum stance articulated by the Irish Government has been associated with the belief that genuine citizenship must be based in the polis (the nation-state). As Mancini and Finlay put it $(2008$, p.81) '[...] the referendum can be seen to work towards "freezing" the nation in time by curtaining the access of "new" ethnic and racial groups'. Elsewhere, economist-come-popular commentator Dave McWilliams (2007 cited Fanning 2008) has been identified as echoing this view that 'culture matters' when it comes to the question of defining Irish citizenship. Referring to the Irish as a 'tribe', in his latest book The Generation Game McWilliams (2007, p.255) insists that 'reason suggests that there are ethnic bonds, commonality and traditions that, as a nation, we value and would like to keep' and that citizenship should be allocated accordingly. According to this reading, the model of citizenship invoked here is that of a particular or 'bounded' model of citizenship. Tracing the idea back to Rousseau and his 'small-is necessary perspective on citizenship', David Miller (1999, p.69) equates bounded citizenship with the republican understandings of citizenship as an active ideal wherein a specific political community is constructed around a bounded 
unit, understood as a finite single entity which is defined on the basis of shared characteristics.

\section{Racial statehood}

The argument against the removal of the constitutional entitlement to birthright citizenship in Ireland in 2004 was articulated by most of the main Opposition parties in conjunction with various sections of Irish civil society. ${ }^{8}$ These pointed out that the term itself 'non-national' was highly misleading as it lumped together a range of categories of persons who could be living in the state for a variety of different reasons, most of which involved a long-term commitment to living and working in the state (NCCRI 2004). They also challenged the statistical evidence presented, as well as the 'fact' of a direct correlation between the constitutional entitlement to birthright citizenship and the arrival of pregnant women in late stages of pregnancy or early stages of labour at Dublin maternity hospitals (King 2004, Irish Council for Civil Liberties 2004). One of the main issues argued at the time by King (2004), which was repeated often, was that the Government could provide no satisfactory breakdown for the overall numbers of births to non-nationals to confirm that they were in fact ‘disproportionate’ (Labour Party 2004, Green Party 2004).

Without the statistical evidence deemed necessary to back up the Government's arguments regarding 'citizenship tourism', it was put forward that the referendum proposal was an attempt to promote 'a racist notion of citizenship and what it means to be Irish by creating a formal category of second-class citizen'

(Oireachtas Debates 4 February 2004, p.495). It was emphasized instead that differentiating between 'genuine' and 'non-genuine' citizens should be seen as an exclusive practice as a result of which, for example, 'migrant women in Ireland have 
been signified as 'other' and stereotyped as sexually active child-makers, deliberately subverting Irish norms of citizenship and nationality' (Lentin 2004b, p.305). As Harrington (2005, p.441) elaborates, '[w] hat marks the Irish state out as such is no longer its exceptional virtue or piety, but the powers of exclusion and expulsion which it shares with all states receiving immigrants and asylum seekers'.

Ronit Lentin explains that to refer to 'racialized exclusions' in this context is to emphasize the 'new ethnicized spaces' in what Sibley (1995) calls 'Ireland's geographies of exclusion' (cited Lentin 2001, p.1). Here, racism is no longer understood as individual prejudice but as 'a system of subordination [which...] makes and keeps people different, separate and unequal' (Lentin and McVeigh 2006, p.24). The alternative suggested, is a post-racial citizenship model which promotes 'a less restrictive understanding of Irish citizenship and belonging' (Brandi 2007, p.43) by encouraging 'an interrogation of how the Irish nation can become other than white (Christian and settled)' (Lentin 2004a, p.6). In contrast therefore to an exclusive model of bounded citizenship based on national ideals of citizenship proposed by the Government, those who oppose the 2004 Citizenship Referendum proposal are understood to have put forward a starkly contrasting inclusive model of citizenship which promotes universal/cosmopolitan ideals regarding the possibilities for rethinking citizenship outside of existing narrow statist parameters.

As Kimberly Hutchings (1999) points out, normally the separation of the particular exclusivist and universal inclusivist models of citizenship, and the theories on which they draw, is seen to revolve around the manner in which one model sees morality and politics as only reconcilable within the nation-state, whereas the other argues that these can be bridged outside the nation-state as well. In this regard it is widely accepted that they do oppose each other. ${ }^{9}$ However I argue in this paper that 
this opposition can be called into question by looking specifically at the ideal of subjectivity which underpins both these models in their analysis of the 2004 Citizenship Referendum. I use the word 'ideal' here to emphasize that as well as an attempt to capture how citizenship does work, there is also a normative assumption common to both models regarding how citizenship must work.

\section{Theoretical basis for existing analysis of 2004 citizenship referendum}

Prior to 2004, the question of Irish citizenship had been defined in terms of the issue of the exclusion of women, Travellers, Jews and African females from the Irish statist project (Meaney 1991, McVeigh 1992, Gray 1996, Lentin 1998, 1999, Fanning 2002, Luibhéid 2003). The 2004 Citizenship Referendum has been interpreted as a similar practice of Othering, with a correspondingly heavy emphasis on the role which gender, race and ethnicity play in this process (Lentin 2004a, 2004b, 2007, Harrington 2005; Lentin and McVeigh 2006, Brandi 2007, Garner 2007, Mancini and Finlay 2008). Such analysis echoes existing work in citizenship scholarship similarly concerned with the issue of immigration which takes as its starting point how individuals and groups thereof are positioned vis-à-vis the state (Kofman 1995, Lister 1997, Lutz 1997, Yuval Davis and Werbner 1999, Yuval-Davis et al 2006). ${ }^{10}$ As the

title of Eleonore Kofman's paper 'Citizenship for Some but not for Others: Spaces of Citizenship in Contemporary Europe' indicates, the aim here has been to challenge the assumed natural boundaries of the state by underlining their fluidity in relation to how individuals are positioned as included and excluded in different ways and according to different discourses. The emphasis here is on the struggle through which the terms of membership of a community are realized. The literature on 'Fortress Europe' is particularly instructive here as that which has extensively theorized the 
exclusive nature, of what Lutz (1997) calls, 'European-ness'. The result is the opposition of two generalized models of citizenship - the exclusive and the inclusive. As Kabeer (2005, p.1) explained, this is because the notion of inclusive citizenship expressly stands opposed here to 'the standpoint of the excluded'.

Within this literature, the importance of 'the state' in defining citizenship has been challenged and the question of citizenship has been explored from sub and supra level perspectives as well as from the national level (Kabeer 2005, Yuval-Davis et al 2006). There has also been enormous importance placed on deconstructing the notion itself of 'individuality' as referring to gender or ethnic neutral, bounded and unattached subjects who willingly engage in the social contract (Lister 1997, Goldberg 2002). This notwithstanding, there remains, however, an understanding within this literature that the state (or a sub category thereof) and the (deconstructed) individual are still analytical categories in their own right. Yuval-Davis et al (2006) capture this in their introduction to The Situated Politics of Belonging. Here they explain that the Marshall understanding of citizenship permits an expanding of the notion of citizenship beyond 'the right to carry a passport' and as such as always (and only) related to the nation-state, to that of 'membership in all kinds of polities from local to global in which people participate in multi-layered ways' (ibid, p.2). At the same time they equally insist however on the necessity of continuing to maintain an understanding of the difference between realms of cultural and economic, as against 'political', inclusion and exclusion in relation to this membership; the latter which we are told is always determined by the boundaries of the subnational, national or supra national state (ibid). What this indicates is that the emphasis on sub-national (local) and supra-national (global) perspectives of citizenship on one hand and the deconstructed notion of individuality on the other, does not undermine an 
understanding of the inter-connected, but ultimately autonomous, relationship between the statist realm where politics is understood to be taking place and, people's interaction in that. This is to point out here that despite moving away from understanding citizenship as something which is exclusively 'bestowed by the state' (Gaventa 2005, p.xii), and towards an understanding of it as something which is constructed in terms of other realms, there remains an emphasis in this literature on the need to always focus in the last instance on how citizenship (and hence subjectivity) is defined vis-à-vis the state (political realm) as that which delineates the boundaries of these other realms. The result is that the notion of autonomous sovereign beings, which exist in the last instance in relation to the state and can be included and excluded, is retained.

Emphasizing the inclusive/exclusive citizenship framework within which dominant international citizenship studies literature operates is not an attempt here to ignore how the debates within this framework can also be broken down along the lines of liberal, communitarian, radical and cosmopolitan theories (on this see Delanty, 2000). Similarly, it is not to ignore Robin Cohen's comments (2006, p.89109) regarding a notable effort elsewhere within this literature to also consider a compromise to the exclusionary focused racial theories of the state in more inclusively focused cosmopolitan alternatives. It is rather to draw attention to the manner in which the framework within which all these theories operate is one which is based on the overall assumption of the need to consider how membership of a fluid, universal humanity can be reconciled with membership of a particular and bounded community.

For example, in existing analysis of the 2004 Citizenship Referendum people were only able to vote Yes or No to the proposal and this can be seen to have 
encouraged extremes in opinions. What then of the self-professed more nuanced options which have been also offered in existing analysis of this event? Many people have argued that these break with the inclusive versus exclusive citizenship framework insofar as they attempt to provide a model of citizenship which is a combination of the two. Bryan Fanning $(2007,2009)$ in particular argues, for example, that concentrating on racism as the only underlying factor of the 2004 Citizenship Referendum as some people have done - by arguing that Ireland, previously a 'racial' state, turned upon the passing of the 2004 Citizenship Referendum into a 'racist' state (Lentin 2004a, Lentin and McVeigh 2006, Garner 2007) - is too simplistic. He suggests instead that the referendum might be better understood in terms of the role which nationalism has played as a concept which is bound up with processes of both exclusion and inclusion (see also Fanning and Munck 2007, Fanning and Mutwarasibo 2007).

In response to this question, I would point out that despite moving from emphasizing exclusive and inclusive models of citizenship as polar opposites, to that of exploring how these models can be interwoven within certain concepts, the framework which is presented here by those such as Fanning or Cohen still presents the politics of citizenship as that which must be defined in terms of the relationship between autonomous persons, or groups of autonomous persons (the universal), and the state (the particular). This indicates that these more 'reasonable' options are not more reasonable in terms of an infinite range of possibilities. Rather, they are simply more reasonable in light of the existing 'spectrum of interpretive dispositions' (Doty 1993, p.298) that created the 'reality' that gave rise to a range of limited possibilities through which the politics of citizenship could be debated in the first place. 
To conclude, the point being made here is that existing analysis of the 2004 Citizenship Referendum mirrors dominant trends in international critical citizenship scholarship by always positing the question of the politics of citizenship in terms of the relationship between subjectivity and the state. It accordingly both reflects and reinforces a certain ideal that the character and location of modern 'political' identity must be located in the claims of state sovereignty (Walker, 1995, p.12). This places an emphasis on the institution of the state and divides responses into either those that justify or those that critique the patterns of exclusion which can be traced through it. Despite a differing of opinion regarding the degree of inclusive-ness or exclusive-ness of the 2004 Citizenship Referendum, the point is that the lowest unit of analysis always remains the individual (albeit a thoroughly deconstructed notion thereof) who is understood in terms of their ability to hold rights against the state.

\section{Challenging the citizenship debate}

I will now consider how Rob Walker's notion of the constitutive subject of citizenship poses a challenge to the existing analysis of the 2004 Citizenship Referendum. As I will discuss, his work specifically questions the emphasis in this type of analysis (which is then used as a departure point to plot all subsequent trajectories) on the notion of the state (or sub category thereof) and (deconstructed) individual, as analytical categories in their own right. Walker instead highlights the manner in which the relationship between citizenship and the modern sovereign territorial state is a historically specific resolution of the question of politics (via diversity and unity) which is extremely significant but not 'true' (timeless) beyond its ability to facilitate a modern expression of political identity. The result is to force us to think about 
dominant concepts of citizenship as being tied to a particular concept of subjectivity as opposed to allowing us to presume that subjectivity has always been theorized via a framework through which a (subjective) self is theorized as sometimes included, sometimes excluded, (and often both) from the (natural) world of states and societies. This intimates that another way of thinking about the 2004 Citizenship Referendum might be possible, albeit extremely difficult to imagine.

\section{Theorizing modern subjectivity}

Unlike existing analysis of the 2004 Irish Citizenship Referendum and that of critical citizenship scholarship more generally, in which the emphasis is on how individuals and groups of individuals are positioned vis-à-vis the state, Rob Walker (1995, 1999, 2003) identifies a need to think about subjectivity in terms of how it is embedded in a historically prior resolution of particularism and universalism which is concentrated in the notion of statehood itself. He does so by pointing to how, with the collapse of the authority structures of Christendom and empire, there was a shift from a pre-modern to a modern framing of the problem of sovereignty. This was a shift in claims about what and where political life might be. His argument is that somewhere between Machiavelli and Hobbes 'the political and communal creatures envisaged in Aristotelian traditions' gave way to an 'unstable modern insistence on a world of free and equal subjects' (2003, p.269). No longer political or communal as when under theological authority, this was the moment at which individuals became divisible from 'politics' and from each other as the authority of God was replaced by the authority of 'Man' (ibid, p.275). In Citizenship After the Modern Subject, Walker (1999) specifically explores this change in how lines were drawn in early-modern Europe in terms of how our understanding of citizenship shifted at this point: from being based 
in a theologically legitimizing feudal status, defined in terms of the status of others above and below (hierarchical exclusion), to that of a self-legitimizing status, defined in terms of membership of a territorial community (spatial exclusion). Most importantly here, Walker points out that in the shift from medieval hierarchies to modern autonomies, a particular understanding of subjectivity - as citizen-subject who is 'at once multiple, specific, individual, and (at least potentially) universal, human, rational' (ibid, p.196) - also became crucial to our understanding of how our political options should be resolved.

Having drawn our attention to the 'assumptions about the past, present and future of what we call politics' (ibid, p.174) Walker is at pains to stress that despite their historical nature, we now take for granted as if they had always been thus ' $[\mathrm{t}] \mathrm{he}$ lines that are drawn through early-modern Europe [...] designated to guarantee separation: of a (subjective) self from the (objective, natural) world' (Walker 2003, p.179). Walker does not deny that there are concerted resistances to this dominant framing, however, he argues that that these too attest to the difficulty of engaging in discussions about citizenship on any other terms than via the question of the state and this notion of autonomous subjectivity as tied thereto (1999, p.171). The problem, as Walker points out, is that most of the alternatives offered - whether these emphasize a specific theory of cosmopolitanism, or merely promote greater inclusion - are themselves already assumed in the prior formulation of the problem as one of particularism and exclusion defined according to the state as analytical category in its own right. The implication here is that state has become both problem and solution regarding questions about the possibilities for political life and that this framing makes the question of citizenship itself when referred back to these statist terms, a ‘crucial but irresolvable problem' (ibid, p.173). As Vaughan-Williams (2007, p.115) 
points out, this is because it is the state which defines the boundaries of exclusion which are then used to (re)define who needs to be 'included' in the state; 'it is precisely the state that produces the foreigner, immigrant, exiled, deported or stateless person in need of greater levels of universal hospitality in the first place'.

In an attempt therefore to separate out understandings of what political life is supposed to be, from understandings of how the modern polis has become inherent in the natural resolution of this question, Walker suggests that citizenship should be (re)conceived not only in relation to where we draw the boundaries of the state or those of the individual but also in relation to how we take for granted the sovereign autonomous 'we' which supposedly exists separate from the boundaries of the state in the first place. He asks us, in other words, to think about citizenship as being tied to a particular notion of subjectivity rather than assuming that subjectivity is naturally autonomous and sovereign. I suggest here that Walker's notion of a constitutive subject of politics (which he refers to as the modern subject) builds on the Foucauldian idea that there is a specific 'kind of individuality which has been imposed on us for several centuries' (Foucault 1982, p.216). ${ }^{11}$ Walker specifically links this idea to our current understanding of politics as located in claims to state sovereignty (Walker 1995, p.12).

In existing analysis of the 2004 Citizenship Referendum the boundaries of the Irish state have been deconstructed by the interrogation which has taken place of notions of Irishness (Lentin 2004a, Crowley et al 2006) as well as that of republicanism/nationalism (Fanning 2007, 2008). Similarly the notion of a gender or ethnic neutral self has been thoroughly challenged in these accounts. There is, however, little evidence that the understanding of the sovereign autonomous 'we' which supposedly exists separate from the boundaries of the state to which Walker 
draws our attention, has been anything more than merely assumed. Instead, the evidence suggests that there is a relatively unproblematic retention in these existing accounts in the last instance of a claim to the original dualism of modern subjectivity which Walker identifies - between 'citizen' (as particular identity defined in terms of the Irish state) and 'Man' (as universal identity defined in terms of humanity). ${ }^{12}$ This is despite the challenge which the presence of the Irish citizen/non-citizen child of non-national parents poses to this dualism. I am referring here to the challenge posed by the exceptional status of children born to non-nationals on the island of Ireland who have (had) an unqualified right to Irish citizenship but whose right to live in Ireland has been suspended (as opposed to revoked) temporarily by a need to secure the 'care and company' of their parents in the first instance. ${ }^{13}$ These children are not entirely 'inside' the Irish state as their citizenship is deferred momentarily, but nor are they 'outside' of the Irish state either as they remain Irish citizens. These are persons who can be conceived of as potential (rather than definite) abusers of Irish citizenship; people who could be deported but not necessarily so. This challenge forms 'a conceptual, empirical and physical breach in the relationship between "human" and “citizens"” (Nyers 1999, p.22) because both possibilities are deferred here, if only momentarily. By concentrating instead, as existing analysis of the referendum does, on the marginalized and exclusionary status of the parents of these children, because this 'makes sense' according to existing understanding of were 'political' subjectivity lies - as either particular (state citizenship) or universal (humanity) - this latter point is ignored. 


\section{Problematizing modern subjectivity}

References by Walker to a specifically modern account of subjectivity which is tied to our understanding of what politics is and must be, can be read as shifting the focus in debates on citizenship with regard to how subjectivity is conceptualized. Instead of an emphasis on coherent categories of subject such as 'foreigner', 'Black', 'immigrant', 'African woman' as in existing analysis of the 2004 Citizenship Referendum, the assumptions underlying the coherency of these subjectivities is questioned. This is done via an exploration of the appeals themselves to sovereign and autonomous subjectivity (as that which can be included or excluded), upon which a (modern) notion of subjectivity is based. The word coherency is used here to capture a dependency on "the lines of analysis that we rely on "to make sense" of our established political categories' (Walker 1999, p.198). The alternative proposed is not 'incoherency' therefore but rather that of 'making strange' (Judith Butler, 2004) ${ }^{14}$ the lines which we have come to take so much for granted, which tell us "how universality and diversity must be related' (Walker 2003, p.283). As opposed to starting with a framework wherein lines are (always already) drawn between a (subjective) self and an (objective) world of states, as is done in existing analysis of the 2004 Citizenship Referendum, Walker intimates at a different framework here which starts from the question specifically of how understandings of being have been required in the last instance to be articulated in terms of a coherent unified entity which can be pointed to as 'included' or 'excluded', as 'abusing' or as 'not abusing'.

As Edkins and Pin-Fat (1999) discuss in detail elsewhere, this is to ask us to consider how a particular symbolic or social order is facilitated through an inscription of sovereign subjectivity as that which defines 'reality' in terms of modern politics, as opposed to presuming that modern politics (a sovereign political order and a 
sovereign autonomous subject) is the only possible political reality. Walker's work essentially calls for a historicizing of the basis by which the question of 'being' has been posed specifically in terms of, and by way of, a particular framing of subjectivity (Irishness) via sovereignty (the Irish statist project). To respond to this call is to take a new starting point for analysis of the 2004 Citizenship Referendum. It is to start specifically with interruptions into assumptions that the modern state is the primary site of legitimate sovereign authority and ask how these cannot, rather than how they can, be subsumed (by redrawing its boundaries) into this dominant understanding of political community.

Existing of the 2004 Citizenship Referendum takes as its natural starting point for questions about citizenship an inclusive/exclusive framework, and then considers on the basis of this, the relation between understandings of 'abuse' and those of exclusion. This (re)produces a modern account of subjectivity as coterminous with the boundaries of the statist project insofar as the notion itself of abuse is correlated with 'being' outside the state (difference) and the notion of non-abuse is correlated with 'being' inside the Irish state (identity). The point is that positing the politics of citizenship in 2004 in this way merely reinforces the statist monopoly on understandings of political community. It does so by (re)affirming the binary nature of the issue: either people are inside the state because they are not considered to be abusing or outside the state because they are considered to be abusing. It then defines the solution - when certain people are found to be outside the state - as widening the scope of the statist project to prevent further such accusations of abuse, thus reaffirming the state as the legitimate sovereign authority. This results in closing down any political possibility which is not defined in terms of a subjectivity which is divided into permutations of identity (inside) versus difference (outside). There is no 
room for ambiguous in-between spaces because any challenge to the statist monopoly on understandings of political community which is opened up by, for example, the transient position which the Irish citizen child of non-nationals born in Ireland occupies, is immediately closed down by 'making sense' of it according to existing political categorizations - in this case their parent's marginal status as non-Irish citizens. As an alternative to this, what is proposed is to concentrate on the transient position which the children of non-nationals born in Ireland occupy as potential abusers of Irish citizenship despite being Irish citizens. The aim here being to expressly explore the possibilities which are opened up by this ambivalent positioning via its challenge to existing understandings regarding the boundaries of political authority and refuse to merely fit this ambivalence back into the dominate statist framework which clearly delineates between 'us' and 'them', the 'included' and the 'excluded'.

\section{Citizenship 'after' the modern subject}

In existing analysis of the 2004 Citizenship Referendum the emphasis on 'privileging the voices of the racialised' (Lentin 2004a, p.6) reveals that there is an assumption that 'they' can be brought 'inside' relations of power to counteract exclusive understandings of community with more inclusive ones. This takes for granted a coherency; a tangible inside which opposes itself to a tangible outside (if only in the last instance). It assumes a resolvability within spatially defined communities along the lines of gender, race, ethnicity and culture. In other words, although the boundaries of this community (understandings of 'where' the lines of the (Irish) state should be drawn) are no longer being taken for granted in critical explorations of the 
referendum, the location of (modern) political identity (understandings of 'how' it is necessary to think about borders as absolute space between inclusion and exclusion) is still bound to the inscription of sovereign subjectivity. Yet citizenship is a site which marks the highly problematic nature of what and where politics occurs - as the debate about Irish citizen children born to non-national parents make clear. Citizenship asks difficult questions about who and how we understand ourselves to be and confirms that the drawing of these lines is always much more complex than the eventual borders which emerge between 'us' and 'them' and between 'racialized' and 'nonracialized', would suggest. Irish citizen children born to non-national parents straddle several positions at once. They do so as agents and therefore as subjects. Their subjectivity cannot be defined in terms of singular agency because they are both agents as Irish citizens who belong and also deprived of agency as people who can be deported because they do not belong.

To consider Walker's work, I propose, is therefore to consider more generally how to interrogate 'the image of clean lines [...] which prevails as a regulative ambition of modern political life' (Walker 2005, p.1). Edkins and Pin-Fat (1999, p.1), identify an important difference in recent attempts to retheorize the political through the notion of 'subjectivity' which is instructive here in considering what is at stake in Walker's work. This is the difference which they identify between attempts which have been made to simply question the notion of the subject as the authentic source of action of meaning, and attempts which have been made to reconceptualize the subject by thinking of it in a new displaced or decentred position. Edkins and Pin-Fat point out that in the latter attempts the emphasis is on a subject without any fixed, essential or permanent identity. Here, the subject is left "not only fragmented but irretrievably split' (ibid, p.1) and it calls the idea itself of sovereignty and its linearities (the self 
versus the other, inside versus outside) into question. The result is an emphasis on the possibility of a politics based upon the ambivalence of subjectivity as an accumulation of encounters and synthesis which cannot be defined in terms of particular groupings or levels of inclusion and exclusion in an overarching sovereign statist project.

\section{The Politics of Sovereign Statehood}

In response to the 2004 Citizenship Referendum proposal which identified certain people as abusing Irish citizenship, a call was made for 'possibilities for other, less restrictive understandings of citizenship and belonging [...]' (Crowley et al 2006, p.22). This was a call to conceptually enlarge the boundaries of the imagined Irish community (those entitled to citizenship). The aim here was defined as that of a 'challenge [to] essentialising views of immigrants and Irishness' (ibid, p.21) in order to point to how those excluded can also be seen as increasingly intertwined within the Irish statist project (Lentin 2007, Fanning and Mutwarasibo 2007, Fanning 2009). The starting point for doing this, as already discussed, has been via an exploration specifically of the statist monopoly on understandings of political community with a

view to deconstructing this. The problem having been thus defined in terms of the question of conceptions of abuse of citizenship by those located outside the Irish state, the solution is understood in terms of an emphasis on a more cosmopolitan Irish community whose existing narrow (white, settled and Catholic) boundaries have been broadened. As Bryan Fanning's book New Guests of the Irish Nation (2009) discusses, the aim is to replace, via 'adaptive nation building', the old understanding of two separate communities (Irish and guests) with an understanding of one large community which has a broader range of identifications. 
What this indicates is that while existing analysis of the 2004 Citizenship Referendum permits a conception of the politics of citizenship in terms of fluid and overlapping identities it does so only insofar as these can be theorized in relation to the sovereign autonomous boundaries of political communities which are enabled by the state. Despite constant deconstruction of understandings of 'them' as outsiders and 'us' as insiders, identity (Irishness) has continued to be conceptualized as ontologically against difference (newness) in terms of how they are two interlinked yet separate unitary entities. These are the categories which are 'constitutive of our modern understanding of political space' (Walker 1995, p.174). The question of the political possibility of citizenship in the Republic of Ireland continues to be understood in relation to the Irish statist project by emphasizing the solution as a more broadened conception within this of what it means to be Irish. We are told how those who have been excluded from the Irish statist project can now be included and how this is realized. Yet, there is little room to explore the implications of how our desire to 'include' - to think of subjectivity in sovereign autonomous entities - presupposes that 'exclusion' must be defined according to the state. There is no space to question the basis of the assumption that the Irish state is the proper legitimate authority in this regard.

\section{Political (im)possibilities}

Moving deliberately away from defining sovereignty and the possibility of politics in terms first and foremost of the state, is to refuse a specifically modern form of understanding ourselves as 'being' (Dillon 1999). In the case of the 2004 Irish Citizenship Referendum, this is to refuse the existing positioning of 'being' in terms of immigrant versus Irish, them versus us, those inside understandings of citizenship 
versus those outside understandings of citizenship, just because these groupings make sense according to established political categories. Instead of taking these boundaries as a starting point to try to understand how conceptions of subjectivity remain embedded in statist understandings of political community, the autonomy of these categories and the manner in which they derive their meaning from the state as analytical category du jour becomes that which needs to be explained.

The strategy offered here to rethink subjectivity is derived from the work of Julia Kristeva. In Strangers to Ourselves (1991) Kristeva considers the lived political experience of groups classified as 'migrants' and 'asylum seekers'. What Kristeva emphasizes is how the geographical and the corporal experience of lived borders (between national and international, between self and other) meet in these images of foreignness. Using Freud's explorations of the unconscious, as that which divides and (re)divides the internal self, to further explore how borders act as symbolic as well as physical signifiers of difference, Kristeva then considers how 'foreignness' can be theorized as 'a symptom' (1991, p.103) which undermines the notion itself of unified selfhood by haunting both identity and difference, inside and outside. In doing so, Kristeva rethinks the human condition as one of rupture within the notion of the (coherent) self and within (coherent) 'selves', as opposed to across them. The point is that instead of merely questioning the identity/difference inside/outside framework within which conceptions of what it is to 'be' a subject are framed by the statist political discourse - this idea of the space of borderline as coterminous with the state Kristeva indicates at how 'being' can be reconceptualised as 'a strange land of borders and otherness ceaselessly constructed and deconstructed' (ibid, p.191). What we are left with then, as Jabri (2009, p.227) points out, is an 'ever-shifting location of 
the borderline that $[\ldots]$ is no longer at the geographic boundaries of the state [nor at the physical boundaries of the subject] but permeates society [and 'self'] within'.

Unlike in existing analysis of the 2004 Irish Citizenship Referendum, Kristeva's work cannot be read as an attempt to (re)think how a 'fractured' subject and their various parts can be (re)conceived of in sovereign coherent terms. Rather, what you have is a re-reading of the ontological status of subjectivity itself - in terms of rupture rather than unity. In Kristeva's work the lines between foreigner and native, identity and difference, us and them, blur. Not only because they are more difficult to identify but because in concentrating on how 'foreignness [...] creeps into the tranquillity of reason itself' (Kristeva 1991, p.170), the metaphysics of presence that sovereignty brings which is required to speak these lines, is displaced by 'an ontological rift that an absence of any sovereignty suggests' (Edkins and Pin-Fat 1999, p.15). This is to leave the reader with an alterative understanding of 'being' as divided in its reliance on the notion of selves which implicates oppositional otherness, rather than an understanding of 'being' as divided in terms of 'the self' which can oppose otherness. This understanding presents a very different conception of how the 'politics' of citizenship might be posed to what is currently presented in existing analysis of the 2004 Irish Citizenship Referendum as the starting point for human 'being' is no longer a metaphysics of presence vis-à-vis the state (sovereignty) but an ontology of plurality and hybridity.

As Vicki Squire (2009) points out, a refusal to engage in an analytical framework that automatically supposes the logic of an inside/outside binary in relation to the question of citizenship, is not to ignore moments when this type of logic does come into play. It is rather to avoid 'automatically presum[ing] such a logic to be manifest' and allow for the possibility that marginality can be conceived of via 
processes of differentiation which are 'irregular, abnormal, strange' as well as sovereign and autonomous (ibid). Thinking in terms of the strategy offered in the work of Julia Kristeva is not to ignore therefore the exclusion which is defined in statist terms but to provide an alternative to the constant renegotiation of the categories of 'them' and 'us' according to this inside/outside binary logic where the focus is (always) on that of replacing 'excluded immigrant' and 'included Irish' with other coherent/ self-contained understandings such as host and newcomer or old and new Irish. ${ }^{15}$ The argument made here is that this allows for the possibility of a politics of citizenship that specifically recognizes the incompleteness of the subject and its fragmented being before lines are drawn along hierarchies of class, status, social order and territorial place and it can be authoritatively declared that 'you' have been constructed as belonging there, 'we' have been constructed as belonging here. This is to move away from the question of what 'makes sense' as to rethink citizenship without the modern subject is precisely not to do so. It is rather to think contemporary politics in terms of how we might 'exceed the discursive space made available by an apparent binary but in effect mutually constitutive choice between state/nation/republic and some half-remembered, half-forgotten cosmopolis' (Walker 1999, p.198). The alternative lines of analysis advocated in this paper will not provide an answer to the politics of citizenship in the Republic of Ireland in 2004 and since, nor elsewhere. What they do offer however is indications of how we might theorize an(Other) starting point for approaching the question of how the 'politics' of citizenship itself could be articulated. This is one which tries not to fix possible responses according to the lines inscribed by modern subjectivities but which actively encourages engagement with the patterns of continuity and diversity that eschew the 
clear, clean lines which tell us who we are and, where the (legitimate) boundaries of political community (must) lie.

\section{Conclusion}

In keeping with the assumption that the state is the site of proper authority, existing analysis of the 2004 Citizenship Referendum 'makes sense' of understandings of the precarious positioning of children born to non-national parents in Ireland as Irish/nonIrish citizens, in terms of their degree of inclusion and exclusion from the Irish statist project. In contrast to this, this article has attempted to consider how moves could be made to explore further the precariousness of this positioning outside of established understandings of where the boundaries of citizenship normally lie.

Sara Salih (2004, p.326) argues that 'making the ordinary world seem strange (rather than unintelligible) constitutes a move towards a more capacious understanding of otherness'. Our task, however, she explains, is not to emancipate ourselves from existing understandings of who we are but to rather to 'replay and recite them in order to reveal the[ir] instabilit[ies]' (ibid). Walker's work as applied here should not therefore be taken to imply that we can move 'beyond' the state, nor beyond a modern conception of subjectivity as sovereign and autonomous. As Foucault pointed out, 'the political, ethical, social, philosophical problem of our days' is not to liberate ourselves from the state but from 'the type of individualization which is linked to the state' (Foucault 1982, p.216). What is proposed is rather the refusal of a certain kind of subjectivity which has monopolized our understanding of ourselves as beings which exist vis-à-vis our relationship with the state, as the only kind of subjectivity. What has been emphasized here is our need to consider how ordinary concepts such as 'foreignness' do not only confirm existing assumptions regarding 
marginalization but can be repeated and replayed to reveal instabilities in existing understandings about where 'the margins' are located, how they are negotiated and what they imply.

Imagining a politics 'beyond the horizons of a sovereign space' where the completeness of the subject is constantly reaffirmed, is no easy task (Walker 1999, p.175). Yet, it is evident that attempts are being made to engage with this possibility in the context of the question of citizenship and belonging on the island of Ireland. Calls have, for example, been made for a counter history of the story of Ireland and its multiple peoples and diasporas, which moves away from the tribal narrative of a core nation of 'old' Celtic and successive invasions of 'new' Irish (MacÉínri 2009). This is to call for imaginations of political horizons which take account of, rather than neutralize, the multiple and overlapping encounters and syntheses which result from uneven combinations and ambiguous margins. It is suggested here that the notion of foreignness as employed by Julia Kristeva helps us consider how we might begin to imagine these alternative political horizons 'that ask after the silences, the margins, the excluded' (Masters 2009, p.124) rather than the sovereign and the coherent.

\section{Acknowledgements}

An earlier version of this paper was presented in June 2009 at the Aberystwyth Lancaster Graduate Colloquium (ALGC). The author gratefully acknowledges the financial support of the Irish Research Council for the Humanities and Social Sciences (IRCHSS) and the suggestions on earlier drafts by Ronaldo Munck and Kenneth McDonagh. Thanks are due finally to the editor and two anonymous reviewers who also provided valuable comments.

\section{References}

Bigo, D. and Guild, E., Eds. 2005. Controlling Frontiers: Free Movement Into and Within Europe. Aldershot: Ashgate 
Brandi, S., 2007. Unveiling the Ideological Construction of the 2004 Irish Citizenship Referendum: A Critical Discourse Analytical Approach. Translocations: The Irish Migration, Race and Social Transformation Review, 2(1), 26-47

Bunreacht na hÉireann: Constitution of Ireland., 2004. Dublin: Government Publications [online] Available from:

http://www.taoiseach.gov.ie/attached_files/html\%20files/Constitution\%20of\%20Irela nd\%20(Eng)Nov2004.htm [Accessed 12 August 2009]

Butler, J., 2004. Changing the Subject: Judith Butler's Politics of Radical Resignification. In: S. Salih and J. Butler, The Judith Butler Reader. Oxford: Blackwell Publishing, 325-356

Centre for the Study of Culture and Society. 2007. Conference: 'The New Irish'?. Dundalk Institute of Technology, 27 September

Cohen, R., 2006. Migration and its Enemies: Global Capital, Migrant Labour and the Nation-State. Hamshire: Ashgate

Crowley, U., Gilmartin, M. and Kitchin, R., 2006. Vote Yes for 'Common Sense Citizenship': Immigration and the Paradoxes at the Heart of Ireland's 'Céad Míle Fáilte'. National Institute for Regional and Spatial Analysis (NIRSA) Working Paper Series, 30, 1-35 
Delanty, G., 2000. Citizenship in a Global Age: Society, culture, politics. Buckingham: Open University Press

Department of Enterprise, Trade and Employment 2003, Total Work Permits Issued By Year and By Category: 1999-2003, Statistical Tables and Company Listings for the Employment Permits Section, [online] Available from: http://www.entemp.ie/labour/workpermits/statistics.htm [Accessed 4 August 2009]

Department of Justice, 2004a. Proposed Citizenship Referendum: Article by Minister for Justice, Equality and Law Reform Mr. Michael McDowell, T.D., Published in Sunday Independent on 14 March 2004. 1-3 [online]. Available from: www.inis.gov.ie/en/inis/article.pdf/files/article.pdf [Accessed 4 August 2009]

Department of Justice, Equality and Law Reform, 2004b. Citizenship Referendum: The Government's Proposals. 1-27 [online]. Available at: www.inis.gov.ie/en/inis/Govtproposals.pdf/Files/Govtproposals.pdf $\quad$ [Accessed 4 August 2009]

Department of Justice, Equality and Law Reform, 2004c. Information Note: Proposal for Constitutional Amendment and Legislation Concerning the Issue of the Irish Citizenship of Children of Non-National Parents. 1-11 [online]. Available from: www.inis.gov.ie/en/inis/information\%20note.pdf/files/information\%20note.pdf

[Accessed 4 August 2009] 
Dillon, M. 1999. The Sovereign and the Stranger. In: J. Edkins, N. Persram. and V.Pin-Fat. Eds. Sovereignty and Subjectivity. London: Lynne Rienner, 117- 140

Dillon, M., 2004. Correlating Sovereign and Biopower. In: J. Edkins, V. Pin-Fat and M. Shapiro, Eds. Sovereign Lives: Power in Global Politics. London: Routledge, 4160

Doty, R.L., 1993. Foreign Policy as Social Construction: A Post-Positivist Analysis of U.S. Counterinsurgency Policy in the Philippines. International Studies Quarterly, 37(3), 297-320

Edkins, J. and Pin-Fat, V. 1999. The Subject of the Political. In: J. Edkins, N. Persram and V. Pin-Fat. Eds. Sovereignty and Subjectivity. London: Lynne Rienner, 1-18

Fajujonu v. Minister for Justice. [1990] 2 IR.

Fanning, B., 2002. Racism and Social Change in the Republic of Ireland. Manchester: Manchester University Press

Fanning, B., 2007. Against the 'Racial State'. Studies: An Irish Quarterly Review, $96(381), 1-8$

Fanning, B., 2008. Review Essay: The Protocols of the Tribe. Translocations: The Irish Migration, Race and Social Transformation Review, 3(1), 186-192 
Fanning, B., 2009. New Guests of the Irish Nation. Dublin: Irish Academic Press

Fanning, B. and Munck, R., 2007. Migration, Racism and Integration: Beyond Vision vs. Pragmatism?. Translocations: The Irish Migration, Race and Social Transformation Review, 2(1), 1-11

Fanning, B. and Mutwarasibo, F., 2007. Nationals/Non-Nationals: immigration, citizenship and politics in the Republic of Ireland. Ethnic and Racial Studies, 30(3), $439-460$

Feldman, A. 2007-8. The New Irish Lecture Series. Boston College Centre for Irish 48

Foucault, M., 1982. Afterword: The Subject and Power. In: H. Dreyfus and P. Rabinow. Michel Foucault: Beyond Structuralism and Hermeutics. Sussex: Harvester Press, 208-226

Foucault, M., 2007. Truth and Power [1977]. In: C. Calhoun, J. Gerteis, J. Moody, S. Pfaff and I. Virk. Eds. Contemporary Sociological Theory (Second Edition). Blackwell Publishers: Oxford, 201-208

Garner, S., 2007. Babies, Bodies and Entitlement: Gendered Aspects of Access to Citizenship in the Republic of Ireland. Parliamentary Affairs, 60(3), 437-452 
Gaventa, J., 2005. Foreword. In: N. Kabeer Ed. Inclusive Citizenship: Meanings and Expressions. London and New York: Zed Books, xii-xiv

Goldberg, D.T., 2002. The Racial State. Oxford: Blackwell Publishing

Government of Ireland (2000) Supporting Voluntary Activity, Government White Paper, Department of Social, Community and Family Affairs, (Dublin: Government Publications), [online] Available at: http://www.pobail.ie/en/CommunityVoluntarySupports/WhitePaperonCommunityand VoluntaryActivity/file,2200,en.doc [Accessed 1 October 2009]

Gray, G., 1996. Irishness - A Global and Gendered Identity?. Irish Studies Review, 16, 24-30

Green Party, 2004. 10 good reasons to Vote No in Citizenship Referendum on June 11, statement launched with Green Party campaign to oppose the citizenship referendum, 21 May $\quad$ [online]. Available from: http://www.greenparty.ie/en/news/news_archive/10_good_reasons_to_vote_no_in_cit izenship_referendum_on_june_11 [Accessed 5 August 2009]

Harrington, J.A., 2005. Citizenship and the Biopolitics of Post-nationalist Ireland. Journal of Law and Society, 32(3), 424-449

Hindess, B., 2002. 'Neo-Liberal Citizenship. Citizenship Studies, 6 (2), 127-143 
Hindess, B., 2005. Citizenship and Empire. In: T. Blom Hansen and F. Stepputat, Eds. Sovereign Bodies: Citizens, Migrants and States in the Postcolonial World. Philadelphia: University of Pennsylvania Press, 241-56

Hutchings, K., 1999. Political Theory and Cosmopolitan Citizenship. In: K. Hutchings and R. Dannreuther. Eds. Cosmopolitan Citizenship. London: Macmillan Press, 3-32

Immigration, Residence and Protection Bill, 2008. [online] Available from: http://www.inis.gov.ie/en/INIS/IRPB_2008.pdf/Files/IRPB_2008.pdf [Accessed 10 October 2009]

Irish Council for Civil Liberties, 2004. ICCL Briefing on Proposal for a Referendum on Citizenship. 21 April. Dublin: ICCL

Irish Nationality and Citizenship Act 2001 [online] Available from: http://acts2.oireachtas.ie/en.act.2001.0015.1.html\#sec1 [Accessed 10 October 2009]

Jabri, V., 2009. Julia Kristeva. In: J. Edkins and N. Vaughan-Williams. Eds. Critical Theorists and International Relations. London: Routledge, 221-234

Kabeer, N., Ed. 2005. Inclusive Citizenship: Meanings and Expressions. London and New York: Zed Books 
King, D., 2004. Immigration and Citizenship in Ireland. Dublin: The Children's Rights Alliance

Kofman, E., 1995. Citizenship for Some but not for Others: Spaces of Citizenship in Contemporary Europe. Political Geography, 14(2), 121-137

Kristeva, J. 1991. Strangers To Ourselves. New York: Columbia University Press

Labour Party, 2004. Citizenship Referendum June 11 $11^{\text {th }}$ Facts? No! Figures? No! Reasons? No! Vote NO!. Labour Party Campaign leaflet, May. [online]. Available from: http://www.labour.ie/download/pdf/citizen_ref_vote_no.pdf [Accessed 5 August 2009]

Lentin, R., 1998. 'Irishness', the 1937 Constitution and Citizenship: a gender and ethnicity view. Irish Journal of Sociology, 8, 5-24

Lentin, R., 1999. Constitutionally excluded: citizenship and (some) Irish women. In: N. Yuval Davis and P. Werbner, Eds. Women, Citizenship and Difference. London: Zed Books, 130-144

Lentin, R., 2001. Responding to Racialisation of Irishness: Disavowed Multiculturalism and its Discontents. Sociological Research Online. [Online], 5(4) Available from: http://www.socresonline.org.uk/5/4/lentin.html [Accessed 14 August 2009] 
Lentin, R. 2004a. From racial state to racist state: Ireland on the eve of the citizenship referendum', Variant, 20. [Online], Available from: http://www.variant.randomstate.org/20texts/raciststate.html [Accessed 6 August 2009]

Lentin, R., 2004b. Strangers and strollers: feminist researching migrant m/others. Women's Studies International Forum, 27(4), 301-314

Lentin, R., 2007. Ireland: Racial state and crisis racism. Ethnic and Racial Studies, $30(4), 610-627$

Lentin, R. and Luibhéid, E. eds. 2004. Representing Migrant women in Ireland and the EU. Special Issue of Women's Studies International Forum, 27(4), 301-304

Lentin, R. and McVeigh, R., 2006. After Optimism? Ireland, Racism and Globalisation. Dublin: Metro Éireann Publications

Lister, R., 1997. Citizenship: Feminist Perspectives. London: MacMillan Press

Lobe and Osayande v. The Minister for Justice, Equality and Law Reform. 2003. Supreme Court of Ireland Decisions [online] Available from: http://www.bailii.org/ie/cases/IESC/2003/3.html [Accessed 10 August 2009]

Luibhéid, E., 2003. Globalization and Sexuality: redrawing racial and national boundaries through discourses of childbearing. In: R. Lentin and E. Luibhéid, Eds. 
Women's Movement: Migrant Women Transforming Ireland. Dublin: Trinity College Dublin, 74-84

Lutz, H., 1997. The Limits of European-ness: Immigrant Women in Fortress Europe. Feminist Review, 57, 93-111

MacÉinrí, P. 2007. Integration Models and Choices. In: Fanning, B. Ed. Immigration and Social Change in the Republic of Ireland. Manchester: Manchester University Press, 214-236

MacÉinrí, P. 2009 'If I wanted to go there I wouldn't start from here: re-imagining a multi-ethnic nation' In: D. Ging, M. Cronin and P. Kirby eds. Transforming Ireland: Challenges, Critiques, Resources. Manchester: Manchester University Press, 38-51

Mancini, J.M. and Finlay, G., 2008. 'Citizenship Matters': Lessons from the Irish Citizenship Referendum. American Quarterly, 60(3), 575-599

Masters, C. 2009. Judith Butler. In: J. Edkins and N. Vaughan-Williams. Eds. Critical Theorists and International Relations. London: Routledge, 114-124

McVeigh, R., 1992. The Specificity of Irish Racism. Race and Class, 33(4), 31-45

McWilliams, D., 2007. The Generation Game. Dublin: Gill and Macmillan 
Meaney, G., 1991. Sex and Nation: Women in Irish Culture and politics. Dublin: Attic Press

Miller, D., 1999. Bounded Citizenship. In: K. Hutchings and R. Dannreuther. Eds. Cosmopolitan Citizenship. London: MacMillan Press Ltd, 60-80

Miller, D. and Linklater, A. 1999. Part II: The Debate. In: K. Hutchings and R. Dannreuther Eds. Cosmopolitan Citizenship. London: MacMillan Press Ltd, 35-80

National Consultative Committee on Racism and Interculturalism (NCCRI), 2004. The Citizenship Referendum: Issues, Observations and Concerns. June., [online] Available from: www.nccri.ie/pdf/AdvocacyPaper3.pdf [Accessed 6 August 2009]

Nyers, P., 1999. Emergency or Emerging Identities? Refugees and Transformations in World Order. Millennium - Journal of International Studies. 28(1), 1-26

Ong, A., 1999. Flexible Citizenship: The Cultural Logics of Transnationality. Durham: Duke University Press

Oireachtas Debates., 4 February 2004. Immigration Bill 2004 [Seanad]: Second Stage (resumed), Dáil Éireann, 757-830

Oireachtas Debates., 21 April 2004. Twenty-Seventh Amendment of the Constitution Bill 2004: Second Stage, Dáil Éireann, 1177-1332 
Oireachtas Debates., 5 May 2004. Twenty-Seventh Amendment of the Constitution Bill 2004: Committee Stage, Seanad Éireann, 752-821

Progressive Democrats., 2004. McDowell address at launch of PD Citizenship Referendum Campaign. [online] Available from: http://www.progressivedemocrats.ie/press_room/949/?keywords=2004+citizenship+r eferendum [Accessed 6 August 2009]

Salih, S. 2004. Introduction. to Changing the Subject: Judith Butler's Politics of Radical Resignification. In: S. Salih and J. Butler. The Judith Butler Reader. Oxford: Blackwell Publishing, 325-326

Squire, V., 2009. On Marginality. ENACT Enacting European Citizenship Project, Work package 3. Enacting mobility: a more democratic European citizenship? [online] Available from: $\quad$ http://www.enactingcitizenship.eu/index.php/sections/blog post/316/ [Accessed 4 September 2009]

Vaughan-Williams, N., 2007. Beyond a Cosmopolitan Ideal: the Politics of Singularity. International Politics, 44, 107-124

Walker, R.B.J., 1995. Inside/Outside: International Relations as Political Theory. Gateshead, Tyne and Wear: Cambridge University Press

Walker, R.B.J., 1999. Citizenship after the Modern Subject. In: K. Hutchings and R. Dannreuther, Eds. Cosmopolitan Citizenship. London: MacMillan Press Ltd, 171-200 
Walker, R.B.J., 2003. Polis, Cosmopolis, Politics. Alternatives 28, 267-286

Walker, R.B.J., 2004. Sovereignties, Exceptions, Worlds. In: J. Edkins, V. Pin-Fat and M. Shapiro, Eds. Sovereign Lives: Power in Global Politics. London: Routledge, 239-249

Walker, R.B.J., 2005. The Doubled Outsides of the Modern International. Revised version of lecture given at the Fifth International Conference on Diversity in Organizations, Communities and Nations. Central Institute of Ethnic Administrators, Beijing, China, June $30^{\text {th }}-$ July $3^{\text {rd }}, 1-10$

Yuval-Davis, N. and Anthias, F. Eds. 1989. Woman-Nation-State. London: Macmillan Yuval Davis, N. and Werbner, P., Eds. 1999. Women, Citizenship and Difference. London: Zed Books

Yuval-Davis, N., Kannabiran, K. and Vieten, U.M., Eds. 2006. The Situated Politics of Belonging. London: Sage Publications

\section{Notes}

${ }^{1}$ Article 2 was the result of a compromise made in 1998 under a peace negotiation (the Good Friday Agreement) between the Irish and British governments, where it was agreed that the existing territorial claim by the Republic to the whole of the island of Ireland (Article 2 inserted in 1937) would be replaced with a constitutional entitlement of all those living on the island to become Irish citizens, but 
only should they wish to do so (Article 2 inserted in 1998). This agreement is also known as The Belfast Agreement and The Stormont Agreement. Prior to 1998, universal entitlement to birthright citizenship on the island of Ireland had been provided for initially in the Freestate Constitution (19221937) and subsequently in statute (from 1937 onwards).

${ }^{2}$ Irish Nationality and Citizenship Act 2001, section 2(c). In 2001 the term non-national replaced the existing references to 'alien' which had been in Irish legislation up until that point since the Aliens Act 1935 (see Irish Nationality and Citizenship Act 2001). Use of the term non-national is highly problematic, not least because it implies that some people living in Ireland have no nationality. This is why, in an attempt to avoid further confusion and/or misrepresentation, I use it here in conjunction with a legal definition as well as the working definition which was used in the 2004 citizenship referendum proposal. Recently the term 'foreign national' has been introduced into draft Irish legislation (see Immigration, Residence and Protection Bill (IRPB) 2008). This term refers specifically to those who are neither Irish citizen nor entitled to enter and be present in the State under the under the European Communities (Free Movement of Persons) (No. 2) Regulations 2006 (S.I. No. 656 of 2006), the European Communities 5 (Aliens) Regulations 1977 (S.I. No. 393 of 1977) or the European Communities (Right of Residence for Non-Economically Active Persons) Regulations 1997 (S.I. No.57 of 1997). The IRPB 2008 was withdrawn by the Government in May 2010 however and therefore the term 'foreign national' has yet to be enshrined in law through this new Bill.

${ }^{3}$ The turnout at this referendum was just under $60 \%$.

${ }^{4}$ In the Republic of Ireland, this understanding of the nature of citizenship has arguably been promoted via the concept of 'active citizenship'. In the Government's White Paper on Supporting Voluntary Activity, it explains that active citizenship 'extends the concept of formal citizenship and democratic society from one of basic civil, political and social and economic rights to one of direct democratic participation and responsibility' (Government of Ireland 2000, p.14).

${ }^{5}$ An additional clause to be inserted at the same time into Bunreacht na hÉireann stipulated that this amendment was not to be implemented retrospectively.

${ }^{6}$ Fianna Gael which was the largest party in opposition at the time agreed with the Government parties that Article 2 of the Constitution did create the potential for abuse of citizenship but expressed dissatisfaction with the timing of the referendum and the lack of All-Party Committee on the matter. While it therefore supported a Yes vote it did not campaign actively for one. 
${ }^{7}$ Between 1999 and 2003 there was an increase in the allocation of work permits within the Republic of Ireland of just over forty thousand (Department of Enterprise, Trade and Employment 2003). Although, as Piaras MacÉínri (2007) points out, it was never possible to say how many people remained living in the country beyond several months, the 2002 Census confirmed an increase in recorded places of birth outside of Ireland for those living in Ireland, in comparison to the previous decade.

${ }^{8}$ This included the Green Party, the Labour Party, Sinn Féin, Irish Council for Civil Liberties, the Children's Rights Alliance, Integrating Ireland, Irish Human Rights Commission and the National Consultative Committee on Racism and Interculturalism.

${ }^{9}$ For an illustration of this opposition, see chapters written as a debate between 'cosmopolitan' and 'bounded' citizenship by Miller, D. and Linklater, A. (1999)

${ }^{10}$ For notable exceptions among citizenship scholarship where the emphasis is not primarily on the state and thereby on defining citizenship in terms of an understanding of power which is centralized and thus imposed upon subjects, but rather where citizenship is presented as a process of subject formation, see for example Ong (1999), Bigo and Guild (2005), and Hindess (2002 and 2005).

${ }^{11}$ The point here is not to draw too many parallels between Foucault's and Walker's work beyond highlighting that both seek to emphasize that sovereignty needs to be understood, in the words of Michael Dillon, as 'idiomatic' (Dillon 2004, p.42).

${ }^{12}$ It should be noted that while a gendered exploration of the 2004 Irish Citizenship Referendum has been undertaken and this has resulted in a renewed focus on this relationship in terms of citizen(ship) and 'Woman' (rather than 'Man'), the dualism itself between particularism and universalism which Walker associates with modern subjectivity, has been retained. See, for example, Lentin, R. and Luibhéid, E. (2004)

${ }^{13}$ In a 1990, the Supreme Court ruled that Miriam Fajujonu (an Irish citizen child born to non-national parents who themselves were undocumented) was permitted to stay in Ireland with the "care, protection and society' of her parents (Fajujonu v. Minister for Justice 1990). As a result of this ruling, it a precedent was set which allowed Irish citizen children born to non-national parents to apply to remain in Ireland on these same terms. This right was never absolute however and in 2003, in another Supreme Court case it was ruled that the right of a child born to non-national parents (who did not have residency rights themselves) to stay in Ireland could be superseded by the importance of the integrity of 
the asylum process and the state's right to control entry into and residence within, the island (Lobe and Osayande v. The Minister for Justice 2003). Exact figures for the total number of people who applied to remain in Ireland between the beginning of 1999 and the end of 2003 on the basis of what became known as an 'Irish born child', are estimated at approximately 10,000 (Oireachtas Debates 5 May 2004, p.801)

${ }^{14}$ Butler argues that this type of approach is in opposition to the approach taken by 'those who believe that we have a certain responsibility to write [and presumably think] not only in an accessible way, but within the terms of already accepted grammar'. She goes on to explain, 'It's not that I'm in favour of difficulty for difficulty's sake; it's that I think there is a lot in ordinary language and in received grammar that constrains our thinking - indeed, about what a person is, what a subject is, what gender is, what sexuality is, what politics can be [...]' (Butler, 2004, p.327-328).

${ }^{15}$ On this concept of the 'new Irish' see Fanning (2009), chapter entitled The 'New Irish'; Feldman (2007-8); Centre for the Study of Culture and Society (2007) 